\title{
Plantations of native shrub species restore soil microbial diversity in the Horqin Sandy Land, northeastern China
}

\author{
DeMing JIANG ${ }^{1}$, ChengYou CAO ${ }^{2 *}$, Ying ZHANG ${ }^{2}$, ZhenBo CUI ${ }^{2}$, XiaoShu HAN² \\ ${ }^{1}$ Institute of Applied Ecology, Chinese Academy of Sciences, Shenyang 110016, China; \\ ${ }^{2}$ College of Life and Health Sciences, Northeastern University, Shenyang 110004, China
}

\begin{abstract}
Caragana microphylla Lam., a leguminous shrub species, plays an important role in revegetation in the degraded ecosystems of the Horqin Sandy Land, Northeastern China. Large areas planted with this shrub have been artificially established as sand binders for soil protection, which might change the composition of soil bacterial communities with the development of sand dune stabilization. In this paper, we investigated the diversity and composition of native soil bacterial communities in the C. microphylla plantation for sand fixation using polymerase chain reaction with denaturing gradient gel electrophoresis (PCR-DGGE) to understand the influence of this plantation on sandy soil ecosystem development. We collected soil samples from plantations with an age sequence of 0 , 9,16 , and 26 years, as well as from the natural community, to identify the differences among soil bacterial communities. The result showed that bacterial abundance and community composition in the sandy land were affected by the age of the $C$. microphylla plantation. Moreover, bacterial diversity decreased with increasing plantation age, and the composition of the bacterial community in the 26-year plantation was similar to that in the natural community. Phylogenetic analysis of bands excised from the DGGE gels showed that members of alpha Proteobacterium, gamma Proteobacterium, Gemmatimonadetes and Chloroflexi were dominant in the sandy land. The stabilization of moving sand dune and development of sand-fixed plantation resulted in an increase of soil fertility, which could drive the structural evolvement of soil bacterial community, and it needs over 20 years for the soil bacterial community to form a stable structure, similar to the case for the natural vegetation.
\end{abstract}

Keywords: soil bacteria; diversity; plantation age; denaturing gradient gel electrophoresis; Horqin Sandy Land

Citation: DeMing JIANG, ChengYou CAO, Ying ZHANG, ZhenBo CUI, XiaoShu HAN. 2014. Plantations of native shrub species restore soil microbial diversity in the Horqin Sandy Land, northeastern China. Journal of Arid Land, 6(4): 445-453. doi: 10.1007/s40333-013-0205-8

The Horqin Sandy Land lies in the east of Inner Mongolia desert, northern China $\left(42^{\circ} 41^{\prime}-45^{\circ} 15^{\prime} \mathrm{N}\right.$, $118^{\circ} 35^{\prime}-123^{\circ} 30^{\prime} \mathrm{E} ; 180 \mathrm{~m}$ to $650 \mathrm{~m}$ asl). In history, many lakes existed here and the landscape was characterized by an extended forest steppe. Animal husbandry has a long history in the region. Since the mid-1970s, the ecological landscape has been dramatically changed because of overgrazing, excessive intense farming, and vegetation devastation by fuel wood gathering, and now is characterized by a landscape of alternated moving, semi-moving, and stabilized sand dunes (Liu et al., 1993). Desertified land accounts for $57.8 \%$ of the total land area in this region (Zhao et al., 2007). Revegetation has been universally accepted as the most effective and useful approach to control desertification as well as to restore the ecological function of degraded ecosystems (Zhang et al., 2004). Since the 1980s, large areas of native shrub plantations have been established as sand binders on moving or semi-moving sandy land to resist wind erosion and improve the environments of this region. The perennial leguminous shrub Caragana microphylla Lam., widely used as the pioneer species in revegetation to stabilize the moving sand dune, is the

\footnotetext{
*Corresponding author: ChengYou CAO (E-mail: caochengyou@163.com) Received 2013-05-17; revised 2013-07-08; accepted 2013-08-04

(C) Xinjiang Institute of Ecology and Geography, Chinese Academy of Sciences, Science Press and Springer-Verlag Berlin Heidelberg 2014
} 
dominant species among the shrubs planted (Cao et al., 2011). Our previous investigations have studied the effects of C. microphylla plantation with an age sequence on the physical, chemical and microbiological properties of sandy soil, and have confirmed that $C$. microphylla growth altered microclimate, increased litter input, and hence, improved soil water holding capacity, contents of total carbon, total $\mathrm{N}$ and microbial biomass $\mathrm{C}$ and $\mathrm{N}$, electrical conductivity, and enzymatic activities (Cao et al., 2008). These improved trends increased with increasing plantation age but decreased with increasing soil depth (Cao et al., 2008). However, the effect of the plantation on soil microfauna composition and diversity remain poorly understood, and no information is available on the changes in the soil microbial components following revegetation in this region.

Since microbes play essential roles in natural ecosystems and affect many important ecological processes, including nutrient acquisition, nitrogen cycling, carbon cycling, and soil formation (Hooper et al., 2000; Smit et al., 2001; Wardle et al., 2004; Kardol et al., 2007; van der Heijden et al., 2008; Medina-Roldán et al., 2012), knowledge about microbial diversity and community composition is important to understand the mechanisms of vegetation restoration. The establishment of sand fixed plantation in arid and semi-arid environments strongly influences the characteristics of the soil microsite and results in nutrient accumulation and the increase in plant production on sandy land. Accordingly, revegetation efforts may lead to corresponding changes in the diversity and composition of soil microbial communities (Zak et al., 2003). For example, the microbial community composition in revegetation soil differed significantly from that in natural soil and mine soil (Herrera et al., 2007). In addition, vegetation establishment in unplanted soil affected the prevalence of some microbial populations (Junier et al., 2009). It is therefore reasonable to propose that microbial communities become increasingly diverse as vegetation develops in sandy land, as a result of the variety of resources that they can utilize. In this study, we examined the diversity and composition of the indigenous soil bacterial communities in an age sequence of the $C$. microphylla plantation for sand fixation in the Horqin Sandy Land. We assumed that the diversity would increase with the plantation age, and the dominant species composition in the soil bacterial communities would differ even though they are in the same climate and soil type.

DNA-based (e.g. 16S rDNA) techniques can provide a comprehensive method for analyzing the diversity and composition of soil bacterial communities under different soil management practices (Muyzer et al., 1993; Prosser, 2002; He et al., 2007; Soule et al., 2009; Ibekwe et al., 2010; Shen et al., 2010). The results from previous researches clearly stated the changes in soil microbial communities caused by environmental change (Smit et al., 2001; Crecchio et al., 2007; Smith et al., 2008). In this study, we combined PCR amplification of 16S rRNA genes and denaturing gradient gel electrophoresis (PCR-DGGE) to determine soil bacterial diversities (including richness, Shannon's Diversity Index and evenness) in an age sequence of $C$. microphylla plantations for sand fixation in the Horqin Sandy Land. Research on microbial community composition in desert environments is insufficient, although a few studies on this topic have been reported (Drees et al., 2006; Smith et al., 2006; Soule et al., 2009; Orlando et al., 2010; Nguyen et al., 2011). The current study is the first report on the composition change in the bacterial community in the Horqin Sandy Land.

\section{Materials and methods}

\subsection{Study area}

This study was conducted at the Wulanaodu Experimental Station of Desertification $\left(43^{\circ} 02^{\prime} \mathrm{N}, 119^{\circ} 39^{\prime} \mathrm{E}\right)$, Chinese Academy of Sciences, Inner Mongolia autonomous region. The station is located in Western Horqin Sandy Land of Northeastern China. The Wulanaodu region has a continental semiarid monsoon climate in the temperate zone. According to data statistics of Wulanaodu Weather Station, the annual mean temperature in the region is $6.3^{\circ} \mathrm{C}$, and the frost-free period is $130 \mathrm{~d}$. Annual precipitation is quite irregular with interannual variability of over $20 \%$ and strong seasonal variability. The mean annual precipitation is $340.5 \mathrm{~mm}, 70 \%$ to $80 \%$ of which occur between May and September. The mean annual pan-evaporation is approximately $2,500 \mathrm{~mm}$.

C. microphylla was planted on moving sandy land around Wulanaodu with the help of straw checker- 
boards beginning in the 1980s. The checkboard was composed of $1 \mathrm{~m} \times 1 \mathrm{~m}$ squares made of straw. The experimental site was enclosed after seeding, and the earliest plantation was 26 years at the time of this study. In the growing season, several annual plants (e.g. S. collina, Bassia dasyphylla, Corispermum thelegium, Chenodium acuminatum and S. viridis) were randomly distributed in the glade and under the shrub crown, and the vegetatation cover is generally less than $10 \%$. Morphological traits of C. microphylla in each age group are listed in Table 1.

\subsection{Experimental design and soil sampling}

Three representative plantations (9, 16 and 26 a) were selected as the experimental sites to study the bacterial diversity in the soil of $C$. microphylla plantation. Four sites (as four replications) from different sand dunes of the same age were selected for sampling. The distance between two sand dunes was less than $1.5 \mathrm{~km}$. In addition, four non-vegetated sand dunes (moving sand dunes) and four sand dunes dominated by natural $C$. microphylla shrubs (NC) over 40 years old in the adjacent planted sites were chosen as 0 -a sites and native sites, respectively. Soil samples were collected in summer (July of 2010). Three C. microphylla shrubs with the same growth conditions were chosen as samples in each $10 \mathrm{~m} \times 10 \mathrm{~m}$ plot. Each soil sample, $20 \mathrm{~cm}$ from the centers and $20 \mathrm{~cm}$ from the edges of the shrubs, were collected in four directions. Then the fresh soils from the 24 sampling points ( 3 plants $\times 2$ microsites $\times 4$ directions) were thoroughly pooled to provide a single soil sample (Fig. 1 ). At the 0 -a plots, soil samples were collected from five sampling points (Fig. 1). Soil samples were collected from a depth of 0 to $10 \mathrm{~cm}$ with a sterile metallic corer $(5-\mathrm{cm}$ in diameter). Large roots, rocks, and animals were removed. A total of 20 soil samples (5 sample plots $\times 4$ replicates) were collected. Half of each sample was kept field-moist in a cooler at $-80^{\circ} \mathrm{C}$, and the other half was air-dried and stored at room temperature.

Table 1 Morphological traits, soil chemical properties and crude DNA contents of C. microphylla plants

\begin{tabular}{|c|c|c|c|c|c|c|}
\hline Item & $0 \mathrm{a}$ & 9 a & $16 \mathrm{a}$ & $26 \mathrm{a}$ & NC & $P$ \\
\hline Mean height (cm) & - & $80.84 \pm 13.83^{b}$ & $95.52 \pm 16.62^{b}$ & $98.81 \pm 20.91^{b}$ & $135.90 \pm 35.85^{\mathrm{a}}$ & $<0.001$ \\
\hline Crown diameter $(\mathrm{cm})$ & - & $75 \times 80$ & $85 \times 95$ & $95 \times 95$ & $150 \times 165$ & - \\
\hline Shoot number (N) & - & $16.58 \pm 5.50^{\mathrm{b}}$ & $17.86 \pm 6.65^{\mathrm{b}}$ & $18.05 \pm 5.96^{\mathrm{b}}$ & $35.81 \pm 10.95^{\mathrm{a}}$ & $<0.001$ \\
\hline Vegetation cover (\%) & $<5$ & 55 & 65 & 70 & 75 & - \\
\hline $\mathrm{pH}$ & $7.02 \pm 0.13^{\mathrm{a}}$ & $6.79 \pm 0.15^{\mathrm{a}}$ & $6.89 \pm 0.12^{\mathrm{a}}$ & $6.96 \pm 0.15^{\mathrm{a}}$ & $6.85 \pm 0.16^{\mathrm{a}}$ & 0.075 \\
\hline Electrical conductivity $(\mu \mathrm{s} / \mathrm{cm})$ & $9.64 \pm 1.29^{c}$ & $30.64 \pm 3.15^{b}$ & $33.85 \pm 5.76^{\mathrm{b}}$ & $43.52 \pm 5.12^{b}$ & $59.12 \pm 12.03^{\mathrm{a}}$ & 0.004 \\
\hline Organic matter (g/kg) & $0.48 \pm 0.12^{\mathrm{c}}$ & $1.75 \pm 0.22^{\mathrm{c}}$ & $2.84 \pm 0.26^{\mathrm{c}}$ & $4.90 \pm 0.60^{\mathrm{b}}$ & $6.40 \pm 0.77^{\mathrm{a}}$ & $<0.001$ \\
\hline Total N (g/kg) & $0.025 \pm 0.003^{c}$ & $0.047 \pm 0.006^{\mathrm{b}}$ & $0.068 \pm 0.009^{b}$ & $0.094 \pm 0.013^{\mathrm{a}}$ & $0.099 \pm 0.012^{\mathrm{a}}$ & $<0.001$ \\
\hline Total P (g/kg) & $0.32 \pm 0.059^{b}$ & $0.38 \pm 0.058^{\mathrm{b}}$ & $0.48 \pm 0.061^{\mathrm{b}}$ & $0.86 \pm 0.13^{\mathrm{a}}$ & $0.92 \pm 0.17^{\mathrm{a}}$ & 0.001 \\
\hline Total K (g/kg) & $2.07 \pm 0.31^{\mathrm{a}}$ & $2.43 \pm 0.19^{\mathrm{a}}$ & $2.32 \pm 0.14^{\mathrm{a}}$ & $2.30 \pm 0.16^{\mathrm{a}}$ & $2.17 \pm 0.12^{\mathrm{a}}$ & 0.153 \\
\hline Available K (mg/g) & $51.11 \pm 10.98^{\mathrm{c}}$ & $99.40 \pm 15.99^{\mathrm{b}}$ & $105.23 \pm 14.81^{\mathrm{b}}$ & $127.65 \pm 13.95^{\mathrm{a}}$ & $134.26 \pm 18.89^{\mathrm{a}}$ & 0.002 \\
\hline Crude DNA $(\mu \mathrm{g} / \mathrm{g})$ & $0.10 \pm 0.025^{\mathrm{c}}$ & $0.36 \pm 0.041^{b}$ & $0.54 \pm 0.12^{\mathrm{b}}$ & $0.75 \pm 0.15^{\mathrm{a}}$ & $0.81 \pm 0.14^{\mathrm{a}}$ & $<0.001$ \\
\hline
\end{tabular}

Note: Means in row followed by different letters are significantly different $(P<0.05)$. Values are mean \pm SD. NC, natural community.

\subsection{Soil chemistry characterization}

Soil $\mathrm{pH}$ and electrical conductivity (EC) were measured in 1:2.5 and 1:5 soil-water ratio suspensions, respectively (ISSCAS, 1978). Part of air-dried and sieved samples was ground and passed through a 0.25-mm mesh for soil organic matter (SOM), total N, total $\mathrm{P}$, total $\mathrm{K}$, and available $\mathrm{K}$ analyses. SOM was measured using the $\mathrm{K}_{2} \mathrm{Cr}_{2} \mathrm{O}_{7}-\mathrm{H}_{2} \mathrm{SO}_{4}$ oxidation method of Nelson and Sommers (1982), and total N was determined using the semimicro-Kjedahl digestion method (Nelson and Sommers, 1982). Soil total P was determined using the Olsen and Dean method (ISSCAS, 1978). Total $\mathrm{K}$ and available K were measured by atomic absorption spectroscopy (ISSCAS, 1978).

\subsection{DNA extraction and PCR-DGGE}

Total environmental DNA was extracted from soil ( 0.7 g) using a Soil DNA Extraction kit (BioTek Corporation, China) following the manufacturer's instructions. The crude DNA content was assayed photometrically 
(a)

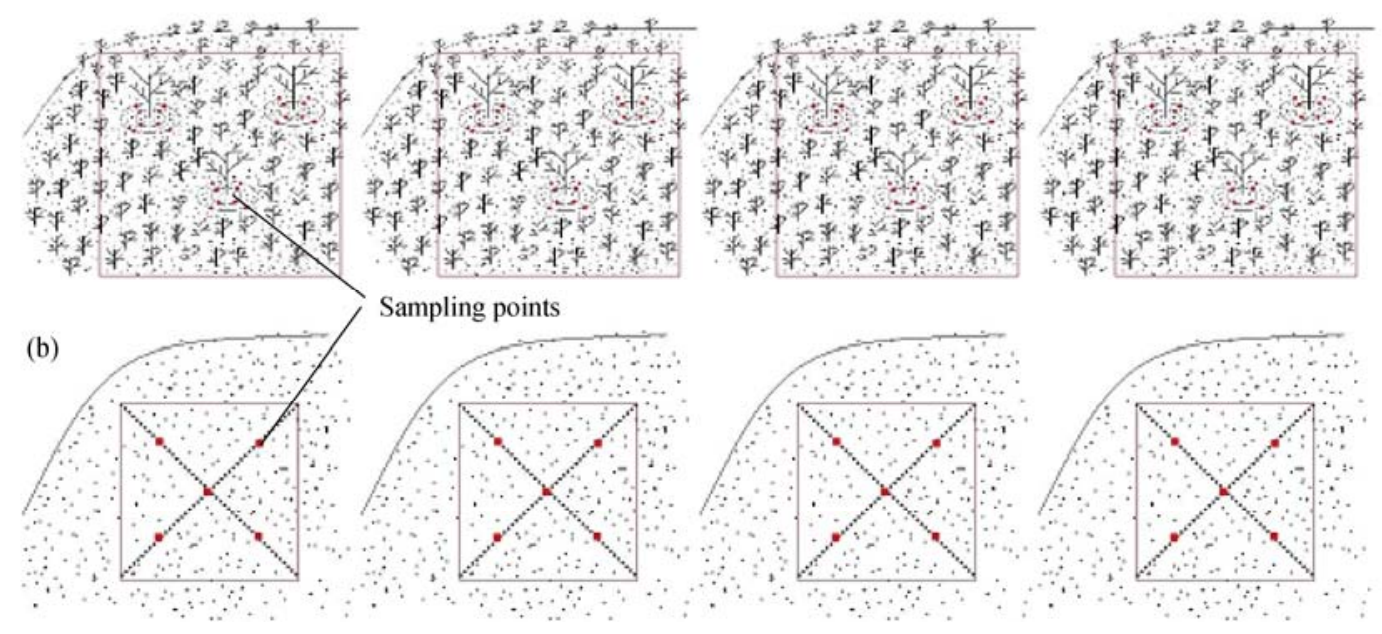

Fig. 1 Schematic representation of the experimental design and soil sampling. (a) Four representative sand dunes (as four replications) of each plantation; (b) four moving sand dunes (0 a)

at $260 \mathrm{~nm}$ with a microplate reader (Biotech $\mu$ Quant). A purification kit was then used to purify the crude DNA extracts. DNA was extracted from the three soil samples (three replications), respectively. Equal amounts of DNA obtained in triplicate were pooled as a sample for PCR and DGGE to reduce spatial heterogeneity (Kuske et al., 2002; Martensson et al., 2009; Orlando et al., 2010).

The 16S rRNA genes were amplified using PCR (Biometra Gradient). PCR primers were specific for conserved bacterial 16S rDNA sequences (Heuer et al., 1997). A DCode ${ }^{\mathrm{TM}}$ System (Bio-Rad Laboratories) was used for DGGE. The PCR amplicons were loaded on $8 \%(\mathrm{v} / \mathrm{v})$ polyacrylamide gels with $30 \%$ to $60 \%$ denaturant gradient. Gels were run for $10 \mathrm{~min}$ at $20 \mathrm{~V}$, then for $5 \mathrm{~h}$ at $70 \mathrm{~V}$, and stained with $\mathrm{EtBr}$ for $30 \mathrm{~min}$. Prominent DGGE bands were excised, reamplified, and again analyzed by DGGE. The PCR products with single bands on the second DGGE were purified for sequence analysis using a PCR purification kit (BioTek Corporation, China). The Shanghai Sangon Biological Engineering Technology \& Services Co., Ltd. (Shanghai, China), performed the sequencing reactions. Similarity comparisons of the partial $16 \mathrm{~S}$ rDNA sequences were performed using the online standard from the National Centre for Biotechnology Information Basic Local Alignment Search Tool (BLAST) program (http://www.ncbi.nlm.nih.gov/blast). Phylogenetic trees were constructed with MEGA4 using the neighbor-joining (NJ) and maximum parsimony (MP) methods to determine the microbial taxa of the obtained bands (Kumar et al., 2004), and bootstrap values were created with 1,000 replicates (Felsenstein, 1985). The GenBank sequences most similar to the soil 16S rRNA gene clones in this study and reference sequences for defining clusters were included in the phylogenetic tree construction.

\subsection{Data analysis}

Quantity One gel analysis software (Bio-Rad) was used for band detection and intensity quantification of DGGE image photographed under UV of a GEL imaging system. Richness, defined as the number of species found, was calculated as the total number of bands per sample. The Shannon-Weaver index of general diversity, $H$, was calculated using the following equation: $H=-\sum P_{i} \ln P_{i}$, where $P_{i}$ is the importance probability of the bands in a gel lane. It was calculated as $P_{i}=n_{i} / N$, where $n_{i}$ is the intensity of a band and $N$ is the sum of all band intensities in the profile (Hoshino and Matsumoto, 2007). The DGGE evenness (E) was calculated as $E=H / \ln (S)$, where $S$ is the total band number of a lane. The Dice Coefficient was computed using the Quantity One software to determine the similarity between two samples. The formula for the Dice Coefficient is $\operatorname{Sim}=200 \times \sum \min \left(S_{i}, t_{i}\right) / \sum\left(S_{i}+t_{i}\right)$, where $S$ and $t$ are vectors representing two lanes in the same band set that are being compared. Cluster analysis, based on the band patterns of communities, was performed to compare the difference between bacterial DGGE patterns among the treatments using the unweighted pair-group method of arithmetic averages 
(UPGMA) applied to digitize DGGE gel images using Quantity One software.

The results of soil chemical properties were reported as mean \pm standard deviations. One-way ANOVA and multiple comparisons followed by an $\mathrm{S}-\mathrm{N}-\mathrm{K}$ test were used to determine the differences among the treatments and performed using SPSS software package. A difference at $P<0.05$ level was considered being statistically significant.

\section{Results}

\subsection{General soil chemical characterization}

Among the soil chemical properties in the different plantations, as expected, electrical conductivity, organic matter, total $\mathrm{N}$, total $\mathrm{P}$, available $\mathrm{K}$, and crude DNA contents varied significantly as well as tended to increase with increasing plantation age $(P<0.05)$. Significant differences in total $\mathrm{K}$ contents and $\mathrm{pH}$ values among the treatments were not found (Table 1).

\subsection{DGGE pattern analysis of soil bacterial com- munities}

Discernible differences in band numbers and intensities among the different samples in the DGGE profile were observed, with 20, 20, 20, 14 and 14 bands detected in the DGGE profiles of the 0-, 9-, 16- and 26-a plantations and the natural community (NC), respectively (Fig. 2). Specifically, bands 10 and 11 were unique to the moving sand dune ( $0 \mathrm{a})$ and were not detected in the other $C$. microphylla communities. While, bands 4 and 6 were unique to the plant community samples and were absent in the moving sand dune. Although bands 8 to 9 and 13 to 22 were present in all the samples, their intensities varied among different plantations. The number of bands represents dominant populations in most soils (Nakatsu, 2007). Many of the dominant DGGE bands were located at equivalent positions along the denaturing gradient, suggesting that they represented similar 16S rRNA alleles common to the samples.

The similarities between the natural community and the 0-, 9-, 16- and 26-a plantation samples were $64.7 \%$, $70.2 \%, 75.0 \%$ and $92.8 \%$, respectively, indicating an increasing trend in similarity. The composition of soil bacterial community in the 26-a plantation is very close to that in the natural community. Cluster analysis divided the DGGE patterns of bacterial communi- ties in the samples into three groups, representing the initial ( $0 \mathrm{a})$, middle (9- and 16-a), and stable periods of plantation (26-a and natural community) (Fig. 3). The diversity and evenness indices of soil bacterial species were higher in the 0 -a (2.84 and 0.89) and 9-a plantation (2.72 and 0.87) than in the 26-a plantation (2.18 and 0.76 ) and natural community (2.17 and 0.74) (Fig. 4).

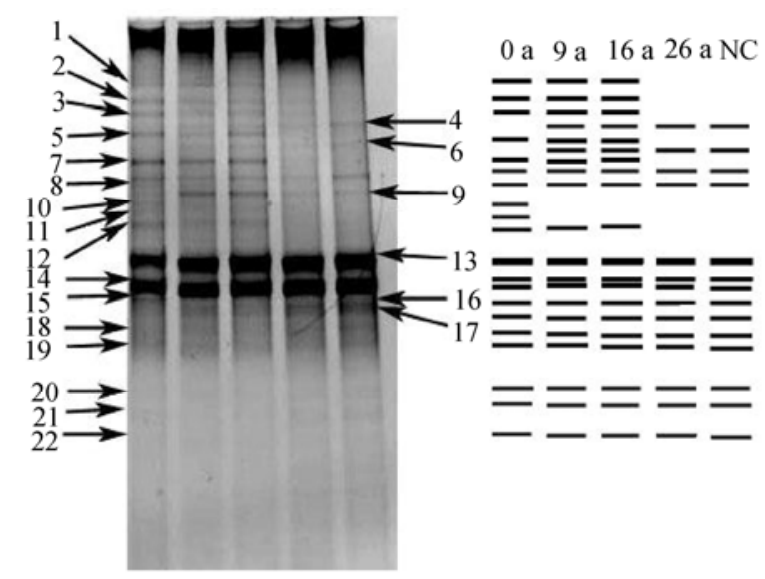

Fig. 2 DGGE profile of amplified 16S rDNA fragments of soil samples from the Horqin Sandy Land. Band position is highlighted with a numbered arrow. Treatments: 0 a, moving sandy dune; 9-a, 16-a and 26-a C. microphylla plantations; NC, natural C. microphylla community.

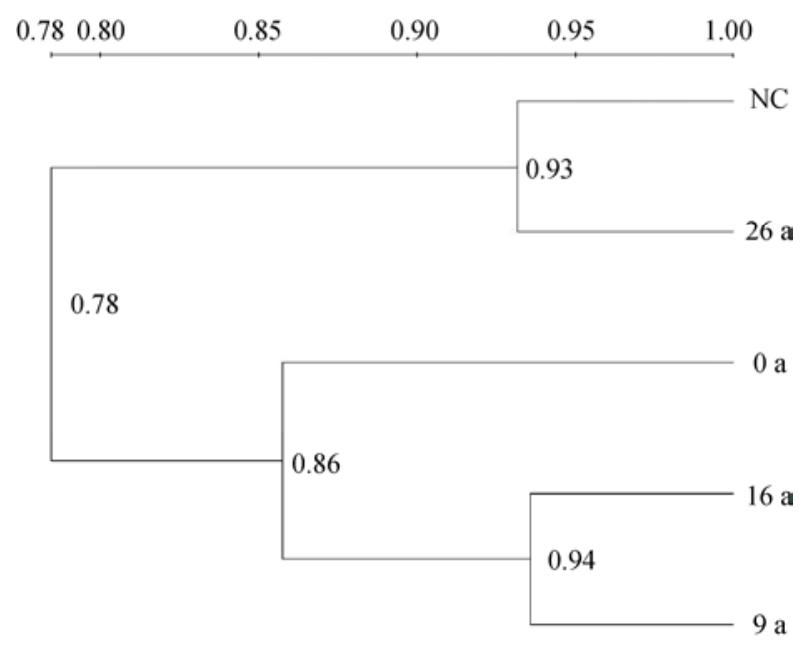

Fig. 3 Cluster analysis (Unweighted Pair Group Method Average linkage) of bacterial 16S rDNA Polymerase Chain Reaction-Denaturing Gradient Gel Electrophoresis profiles

\subsection{Phylogenetic analysis of DGGE band}

Twelve DGGE bands were excised, reamplified, and successfully sequenced. To infer the phygenetic relationship of all sequenced bands accurately, neighborjoining (NJ) and maximum parsimony (MP) methods 
were both used to construct phylogenetic trees, and obtained trees were the same (Fig. 4). Phylogenetic analysis showed that sequences of bands were clus-

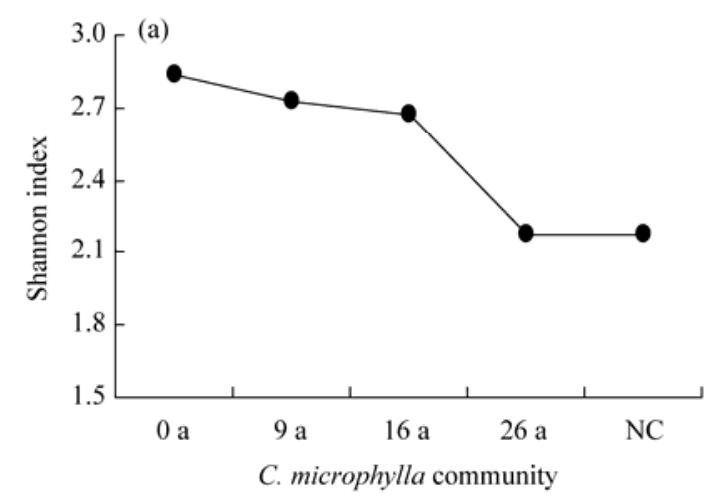

tered as the following main groups: alpha Proteobacterium, gamma Proteobacterium, Chloroflexi and Gemmatimonas. (Fig. 5). Four sequences in this study

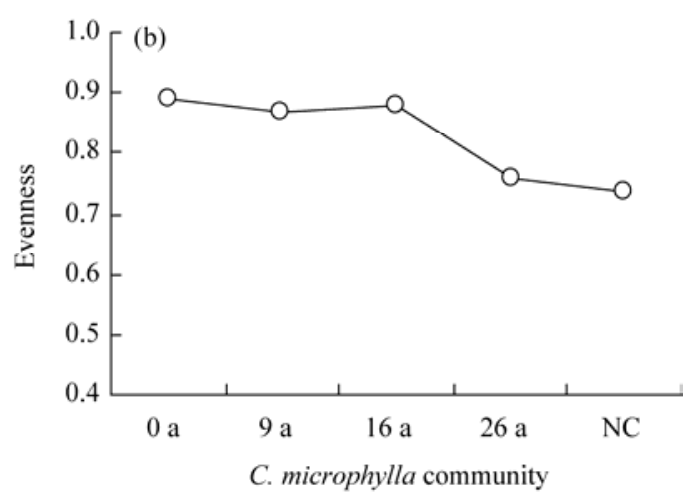

Fig. 4 Shannon index $(H)$ and evenness $\left(E_{H}\right)$ of soil microbial 16S rRNA gene diversity in different sand-fixed plant communities

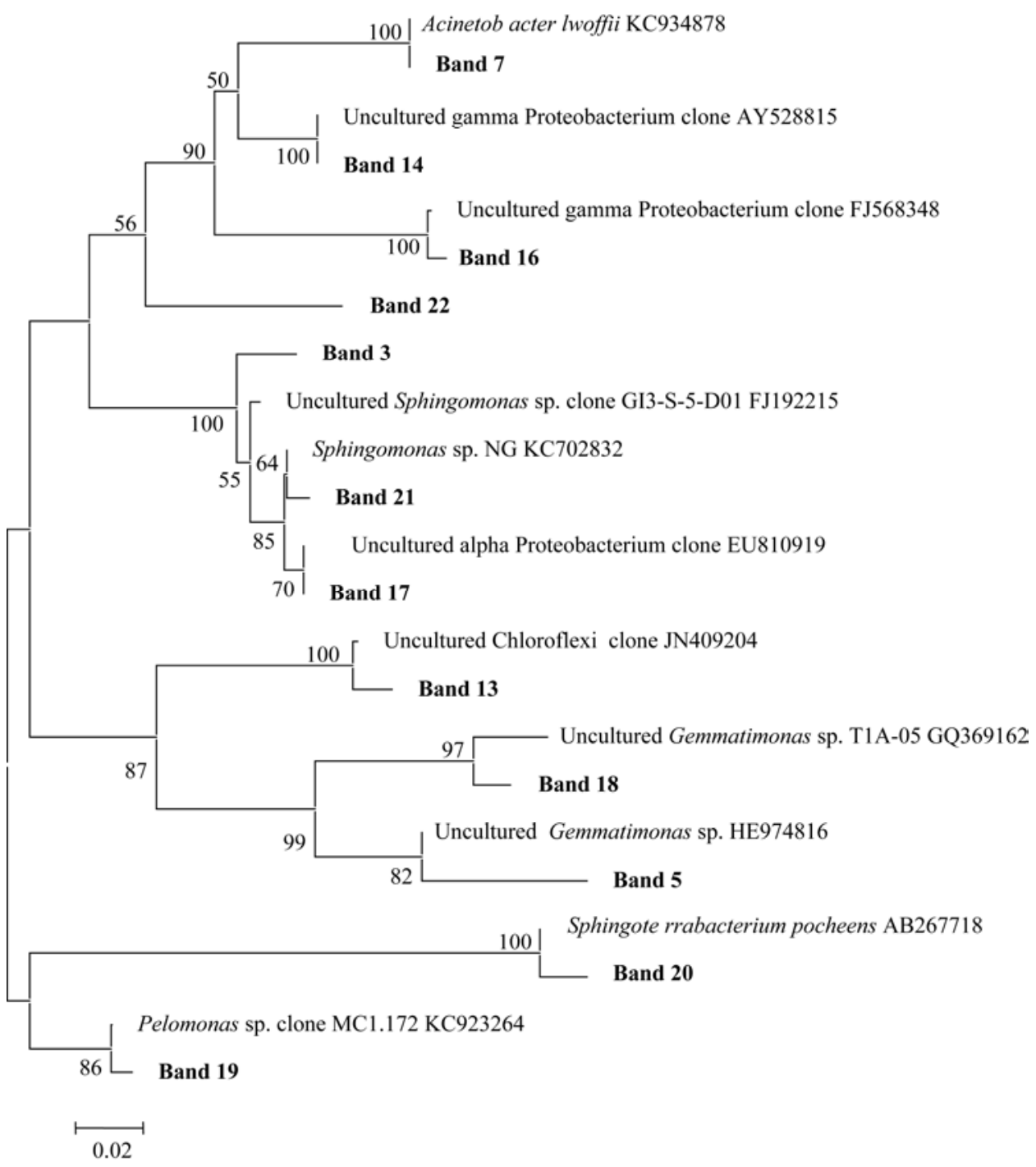

Fig. 5 Phylogenetic tree for unique 16S rRNA gene sequences. Tree was constructed with partial 16S rRNA gene sequences, obtained from 0-, 9-, 16- and 26-a, as well as natural C. microphylla community samples, and additional closely matched sequences from GenBank. 
had close relationship with that of culturable Acinetobacter, Sphingomonas, Sphingoterrabacterium and Pelomonas, respectively. While two sequences belonged to uncultured Gemmatimonas sp. Acinetobacter-related sequence (band 7) was only observed in the 0 -, 9- and 16-a plantation samples, whereas the others were detected in all the samples.

\section{Discussion}

Microbes have difficulty surviving in moving sand dunes because of the extremely low organic matter content and severely arid, as well as unstable environment. Thus, less species and quantity of microbes would be expected in moving sand dunes. However, the present study shows that more than 20 species of bacteria are present in the moving sand dune in the Horqin Sandy Land. Although the metabolism and proliferation of most soil bacteria may be restricted in the moving sand dunes, some bacteria with the ability to use limited nutrients for growth survive. Soil environmental changes can result in changes in microbial diversity of some functional groups. Orlando et al. (2010) reported that short and sporadic rainfall in the southern end of the Atacama Desert (Northern Chile) promoted plant survival and produced a short time of "desert bloom" that resulted in the decreased diversity of soil ammonia-oxidizing bacteria.

The original moving sand lands were gradually stabilized with the establishment and development of $C$. microphylla plantations. Vegetation cover, the number of invasive plant species and their abilities to reduce wind speed and intercept dust deposition increased with the plantation age, resulting in an increased soil organic matter, total $\mathrm{N}$, total $\mathrm{P}$, available $\mathrm{K}$ and electrical conductivity in the desertified sandy soils (Table 1). The improvement in soil nutrients and microenvironment with the increase in plantation age may contribute to the growth and proliferation of some specific species of bacteria. In the present study, the crude DNA contents extracted from the soil samples increased following the increase in plantation age (Table 1). This phenomenon indicates that the total amount of soil bacteria increased with the improvement of the soil environment. However, the number of dominant bacterial species, the Shannon's diversity index and evenness of microbial community decreased with the development of C. microphylla plantations (Figs. 2 and 4). Compared with the case for other ecosystems, the soil nutrients are very scarce in sandy land, which could lead to a predominance of a few bacterial species or the disappearance of others because of competition, e. g. Acinetobacter was observed in the 0-, 9and 16-a samples, but not in the 26-a and natural community samples.

The cluster analysis divided the DGGE patterns of bacterial communities in the samples into three groups (i.e. 0-, 9- and 16-a, 26-a and NC, respectively) (Fig. 2 ), indicating the development trend of the composition structure of soil bacterial community under the $C$. microphylla plantations. Generally, the natural plant community is considered to have a stable composition, including soil bacteria composition. In this study, the composition of the soil bacterial community in the 26-a plantation was very similar to that of the natural community, indicating that over 20 years is needed for the formation of a stable soil bacterial community composition when the $C$. microphylla plantation is established on moving sand dune. Our results also suggest that the improvement of soil environment and amelioration of soil nutrients can increase the bacterial amount, but lead to the decreases of richness and diversity index of soil bacterial community in the semi-arid sand land. Therefore, the hypothesis that moving sand dune stabilization using vegetation reestablishment increases soil bacterial diversity is possibly disproved.

Phylogenetic analysis of the bacterial 16S rRNA gene suggests that Sphingote rrabacterium, Sphingomonas, Acinetobacter, Pelomonas species of Proteobacterium and Gemmatimonas were identified by PCR-DGGE in the current study, suggesting their dominance in the sandy land. The wide distribution and diversity of Sphingomonas have been demonstrated in numerous surveys of environments varying greatly in physical and biogeochemical characteristics (Eguchi et al., 1996; Bowman et al., 1997; Fegatella and Cavicchioli, 2000; Bending et al., 2003). Many Sphingomonas species can survive in extreme environments under poor nutrient conditions using simple molecular nutrients and by decomposing complex organic substances. Pelomonas can also survive and thrive in extreme environments with low temperature and poor nutrition, e.g. in snow at the summit (8,201 m asl) of Cho Oyu Mountain, Tibet (Tong et al., 2008). 
Zhang et al. (2007) demonstrated that Proteobacteria is the predominant group in the rhizoplane of a $C$. korshinskii plantation in the North Loess Plateau in China. Many alpha Proteobacteria, including Rhizobium, Sinorhizobium and gamma Proteobacteria, beneficial to plant growth by inducing the formation of root nodules or symbiosis, are present in the rhizoplane. The Rhizobium distribution in the soil of the C. microphylla plantations is unknown and needs to be further studied. Although this study has not wholly identified the diversity of soil bacteria present in the Horqin Sandy Land, microbes obviously possess the capacity for enduring severe drought and poor nutrition environments that are not favorable for most plant species. The phylogenetic distribution of the bacteria identified in this study suggests that arid and barren sandy environments considerably influence the distribution of specific bacterial divisions.

\section{Conclusions}

We have characterized the composition of soil bacterial community in the Horqin Sandy Land and have found that alpha Proteobacterium, gamma Proteobacterium, Gemmatimonadetes and Chloroflexi were dominant in the sandy land. Our results showed that the establishment and development of C. microphylla plantations in moving sand dune affect the soil bacterial abundance and composition of bacterial community. The improvement of soil fertility can increase the total amount of soil bacteria, but decrease the soil bacterial diversity. The results provoke questions of interest for future study. With the accumulated information on the composition of the soil bacterial community, efforts can be made to isolate these species using recently identified techniques for further utilization.

\section{Acknowledgements}

This work was supported by the National Natural Science Foundation of China (40871247) and the China National Twelfth Five-year-plan Key Project (2012BAD16B0302). The authors thank the members of the Wulanaodu Station of Desertification Research, Chinese Academy of Sciences for their technical assistance.

\section{References}

Bending G D, Lincoln S D, Sorensen S R, et al. 2003. In-field spatial variability in the degradation of the phenyl-urea herbicide isoprotu- ron is the result of interactions between degradative Sphingomonas spp. and soil pH. Applied and Environmental Microbiology, 69(2): 827-834.

Bowman J P, McCammon S A, Brown M V, et al. 1997. Diversity and association of psychrophilic bacteria in Antarctic Sea ice. Applied and Environmental Microbiology, 63(8): 3068-3078.

Cao C Y, Jiang D M, Teng X H, et al. 2008. Soil chemical and microbiological properties along a chronosequence of Caragana microphylla Lam. plantations in the Horqin Sandy Land of Northeast China. Applied Soil Ecology, 40(1): 78-85.

Cao C Y, Jiang S Y, Zhang Y, et al. 2011. Spatial variability of soil nutrients and microbiological properties after the establishment of leguminous shrub Caragana microphylla Lam. plantation on sand dune in the Horqin Sandy Land of Northeast China. Ecological Engineering, 37(10): 1467-1475.

Crecchio C, Curci M, Pellegrino A, et al. 2007. Soil microbial dynamics and genetic diversity in soil under monoculture wheat grown in different long-term management systems. Soil Biology \& Biochemistry, 39(6): 1391-1400.

Drees K P, Neilson J W, Betancourt J L, et al. 2006. Bacterial community structure in the hyperarid core of the Atacama Desert, Chile. Applied and Environmental Microbiology, 72(12): 7902-7908.

Eguchi M, Nishikawa T, Macdonald K, et al. 1996. Responses to stress and nutrient availability by the marine ultramicrobacterium Sphingomonas sp. strain RB2256. Applied and Environmental Microbiology, 62(4): 1287-1294.

Fegatella F, Cavicchioli R. 2000. Physiological responses to starvation in the marine oligotrophic ultramicrobacterium Sphingomonas sp. Strain RB2256. Applied and Environmental Microbiology, 66(5): 2037-2044.

Felsenstein J. 1985. Confidence limits on phylogenies: an approach using the bootstrap. Evolution, 39(4): 783-791.

He J Z, Shen J P, Zhang L M, et al. 2007. Quantitative analyses of the abundance and composition of ammonia-oxidizing bacteria and ammonia-oxidizing archaea of a Chinese upland red soil under long-term fertilization practices. Environmental Microbiology, 9(9): 2364-2374.

Herrera A, Hèry M, James E M, et al. 2007. Species richness and phylogenetic diversity comparisons of soil microbial communities affected by nickel-mining and revegetation efforts in New Caledonia. European Journal of Soil Biology, 43(2): 130-139.

Heuer H, Krsek M, Baker P, et al. 1997. Analysis of actinomycete communities by specific amplification of genes encoding $16 \mathrm{~S}$ rRNA and gel-electrophoretic separation in denaturing gradients. Applied and Environmental Microbiology, 63(8): 3233-3241.

Hooper D U, Bignell D E, Brown V K, et al. 2000. Interactions between aboveground and belowground biodiversity in terrestrial ecosystems: patterns, mechanisms, and feedbacks. Bioscience, 50(12): 10491061.

Hoshino Y T, Matsumoto N. 2007. DNA-versus RNA-based denaturing gradient gel electrophoresis profiles of a bacterial community during replenishment after soil fumigation. Soil Biology \& Biochemistry, 39(2): 434-444.

Ibekwe A M, Poss J A, Grattan S R, et al. 2010. Bacterial diversity in 
cucumber (Cucumis sativus) rhizosphere in response to salinity, soil pH, and boron. Soil Biology \& Biochemistry, 42(4): 567-575.

Institute of Soil Science, Chinese Academy of Sciences (ISSCAS). 1978. Physical and Chemical Analysis Methods of Soils. Shanghai: Shanghai Science Technology Press, 7-59.

Junier P, Carùc M, Witzel K P. 2009. Effect of common bean (Phaseolus vulgaris L.) on the community composition of ammonia-oxidizing bacteria in soil previously cultivated with Medicago sativa. European Journal of Soil Biology, 45(3): 252-258.

Kardol P, Cornips N J, van Kempen M M L, et al. 2007. Microbe-mediated plant-soil feedback causes historical contingency effects in plant community assembly. Ecological Monographs, 77(2): 147-162.

Kumar S, Tamura K, Nei M. 2004. MEGA3: integrated software for molecular evolutionary genetics analysis and sequence alignment. Briefings in Bioinformatics, 5(2): 150-163.

Kuske C R, Ticknor L O, Miller M E, et al. 2002. Comparison of soil bacterial communities in rhizospheres of three plant species and the interspaces in an arid grassland. Applied and Environmental Microbiology, 68(4): 1854-1863.

Liu X M, Zhao H L. 1993. Comprehensive Strategy for Eco-environmental Control in Horqin SandLand. Lanzhou: Gansu Science and Technology Publishing-house, 88-115.

Martensson L, Diez B, Wartiainen I, et al. 2009. Diazotrophic diversity, nifH gene expression and nitrogenase activity in a rice paddy field in Fujian, China. Plant and Soil, 325(1): 207-218.

Medina-Roldán E, Paz-Ferreiro J, Bardgett R D. 2012. Exclusion affects soil and plant communities, but has no impact on soil carbon storage in an upland grassland. Agriculture, Ecosystems and Environment, 149(1): 118-123

Muyzer G, de Waal E C, Uitterlinden A G. 1993. Profiling of complex microbial populations by denaturing gradient gel electrophoresis analysis of polymerase chain reaction-amplified genes coding for 16S rRNA. Applied and Environmental Microbiology, 59(3): 695-700.

Nakatsu C H. 2007. Soil microbial community analysis using denaturing gradient gel electrophoresis. Soil Science Society of America Journal, 71(2): 562-571.

Nelson D W, Sommers L E. 1982. Total carbon, organic carbon and organic matter. In: Page A L. Methods of Soil Analysis, Part 2. $2^{\text {nd }}$ ed. Madison: American Society of Agronomy, 539-577.

Nguyen L M, Buttner M P, Cruz P, et al. 2011. Effects of elevated atmospheric $\mathrm{CO}_{2}$ on rhizosphere soil microbial communities in a Mojave Desert ecosystem. Journal of Arid Environments, 75(10): 917-925.

Orlando J, Alfaro M, Bravo L, et al. 2010. Bacterial diversity and oc- currence of ammonia-oxidizing bacteria in the Atacama Desert soil during a "desert bloom” event. Soil Biology \& Biochemistry, 42(7): 1183-1188.

Prosser J I. 2002. Molecular and functional diversity in soil micro-organisms. Plant and Soil, 244(1): 9-17.

Shen J P, Zhang L M, Guo J F, et al. 2010. Impact of long-term fertilization practices on the abundance and composition of soil bacterial communities in Northeast China. Applied Soil Ecology, 46(1): 119-124.

Smit E, Leefland P, Gommans S, et al. 2001. Diversity and seasonal fluctuations of the dominant members of the bacterial soil community in a wheat field as determined by cultivation and molecular methods. Applied and Environmental Microbiology, 67(5): 2284-2291.

Smith J J, Tow L A, Stafford W, et al. 2006. Bacterial diversity in three different Antarctic cold desert mineral soils. Microbial Ecology, 51(4): 413-421.

Smith N R, Kishchuk B E, Mohan W W. 2008. Effects of wildfire and harvest disturbances on forest soil bacterial communities. Applied and Environmental Microbiology, 74(1): 216-224.

Soule T, Anderson I J, Johnson S L, et al. 2009. Archaeal populations in biological soil crusts from arid lands in North America. Soil Biology \& Biochemistry, 41(10): 2069-2074.

Tong X M, Chen F, Yu J, et al. 2008. Phylogenetic identification and microbial diversity in snow of the summit (8201 m) of Cho Oyu Mountain, Tibet. Chinese Science Bulletin, 53(21): 3317-3323.

van der Heijden M G A, Bardgett R D, van Straalen N M. 2008. The unseen majority: soil microbes as drivers of plant diversity and productivity in terrestrial ecosystems. Ecology Letters, 11(3): 296-310.

Wardle D A, Bardgett R D, Klironomos J N, et al. 2004. Ecological linkages between aboveground and belowground biota. Science, 304(5677): 1629-1633.

Zak D R, Holmes W E, White D C, et al. 2003. Plant diversity, soil microbial communities, and ecosystem function: are there any links? Ecology, 84(8): 2042-2050.

Zhang T, Zhao H, Li S, et al. 2004. A comparison of different measures for stabilizing moving sand dunes in the Horqin Sandy Land of Inner Mongolia, China. Journal of Arid Environments, 58(2): 202-213.

Zhang W, Hu Y G, Huang G H, et al. 2007. Soil microbial diversity of artificial peashrub plantation on North Loess Plateau of China. Acta Microbiologica Sinica, 47: 751-756.

Zhao H L, Zhou R L, Su Y Z, et al. 2007. Shrub facilitation of desert land restoration in the Horqin Sand Land of Inner Mongolia. Ecological Engineering, 31(1): 1-8. 